\title{
SELECTED FACTORS SHAPING THE INTERNATIONAL POSITION OF SLOVAKIA SINCE THE COLLAPSE OF THE COMMUNIST SYSTEM
}

\begin{abstract}
Since 1989 there have been many internal and external factors which have shaped the international position of Slovakia. The Slovak foreign policy has come through many tests until today. The current international situation on the European and global level creates new challenges for the foreign policy of the Slovak Republic. Although many difficulties have come, the Slovak Republic has shown the capacity to create responsible positions in the dynamically changing international environment, in dialogue with its transatlantic and European allies. This paper has the ambition to identify the key political factors and turning points in the internal and external political development, which have shaped the international position of the Slovak Republic and have significantly affected the credibility of the Slovak Republic in the framework of regional (V4), European (EU) and global (NATO, UN) structures since 1989.
\end{abstract}

KEYWORDS: foreign policy, democracy, reform, Czechoslovakia, Slovakia, integration, EU

\section{THE POLITICAL AND SECURITY ARCHITECTURE AFTER THE COLLAPSE OF THE COMMUNIST SYSTEMS}

The Cold War has ended between 1980's and 1990's, with the collapse of the central planned system, along which have also failed all totalitarian communist systems in Europe. The Iron Wall had fallen and with it the democratization process of society had started, and the differences between linguistically close nations began to show. The result was a disruption of all 
three multi-national states - the USSR, Czechoslovakia and Yugoslavia. The East-Central strip of Europe split into small nation states, many of which are only a few tens of thousands of square kilometers in area and with less than 5 million inhabitants. This prevents the creation of a regional power centre, and countries are therefore forced to seek new guarantees of their safety (Baar, 2000, p. 135).

Rapid dissolution of the Warsaw Pact and Comecon (Council for Mutual Economic Assistance) in 1991 meant a radical change that shook the stability of respective countries. This, coupled with dramatic transformational changes, led to the temporary destabilization of the economy of Poland, Czechoslovakia and Hungary (as well as Romania, Bulgaria, etc.).

The change of the political and security architecture on the European and global scale was reflected in the considerations and calculations of democratically elected elites in Czechoslovakia. The idealistic tendencies have manifested themselves into the first concepts of foreign policy and security orientation, namely into the preferred "non-aligned" political and security architecture. The CSCE (OSCE since 1995) has become the centre of attention, as an acceptable pillar of Czechoslovak foreign policy and a key building block of the security architecture in Europe (Vlček, Kaščáková, 2010, p.17). On the other hand, the CSCE appeared to be an inadequate security provider in the context of events in the Baltic countries and Yugoslavia. In the absence of any effective safeguards, sanctions and enforcement mechanisms, the CSCE was unable to move beyond a merely consultation club. After this experience, a new orientation towards NATO and EU membership began to form. The priority was to rapidly obtain security guarantees in the power vacuum of that time, which was created after the Soviet withdrawal from the affected territory. NATO had proven to be the only possible guarantor of the so called "hard security” (10 June 1991 - Krakow) (Vlček, Kaščáková, 2010, p. 17).

\section{TURNING POINTS IN THE INTERNAL DEVELOPMENT IN SLOVAKIA BETWEEN 1989-1993}

The political and socio-economic development of the country in a new democratic system cannot be understood without getting acquainted with the main participants - the political parties. It is because they determined 
the course of the country, law creation and measures taken by the individual governments based on coalition agreements. In the Slovak environment it was shown that the quality of a democratic political environment or its lack thereof largely depends upon the quality of political parties. The development of democracy was also influenced by further factors such as the civilisation background, sociocultural development, historical experience, tradition as well as other external factors.

The new freedom and democracy opened discussions, which had been considered taboo or marginalised in the previous decades; this has resulted in many problems which had been for a long-time neglected. The issue of the position of Slovakia within the Czech-Slovak relationship proved its key importance further along the way. The emergence of the issue was triggered by the "dash war". The Slovaks called for a dash to be inserted between the country names: Czecho-Slovakia, however, the Czechs demanded to keep the traditional name - Czechoslovakia. This conflict was rooted in the fact that Slovaks perceived the state as two different joined wholes, (historically, Slovakia had not been a part of the Czech Kingdom), however, the Czechs perceived their own identity as Czechoslovak. A compromise was achieved by naming the country the Czech and Slovak Federative Republic (Kováć, 1998, p. 319-320).

Another conflict was related to the allocation of competencies between the federal government and the two republic ones. A compromise was again achieved in the so-called Competency Law, which split competencies between the federal and republic bodies, thus decreasing the power of federal laws and institutions.

The new constitution represented a third problem. The negotiations took 16 months and as a result an agreement proposal was submitted by the republic parliament (it was prepared in Milovy na Morave in February 1992). The 20-member presidency of the Slovak National Council (SNC) failed to adopt the submitted proposal by a vote of 10 to 10 . After that, the Czech National Council presidency refused to continue the negotiations. The agreement proposal, which addressed the state law system principles between the two parliaments, was therefore never ratified (Kováč, 1998, p. 320). 
The period of 1989-1992 was in Czechoslovakia marked by turbulent emotions, a lack of concept and a lack of understanding for a "complex process of change which was taking place simultaneously on several levels of our reality" (Sičák, 2006, p.184). The transformation process found itself entangled in political, economic and social difficulties. There have been many important turning points in the post 1989 development. All free elections in 90 's could be characterized as so called "critical elections", representing turning points in the political development. The economic transformation represented the critical issue with significant political consequences.

In the early stages of the reform, the political leadership of Czechoslovakia decided to opt for a method called "shock therapy". In the context of the ideas of economic neoliberalism, it was necessary to carry out the reform multiple steps at once, in order not to further prolong the situation in which the rules of a planned economy were increasingly getting dysfunctional, and the rules of a market economy were not yet fully implemented, and therefore did not work properly. A growth of unemployment (1990-1, 6\%, 1992-10,4 \%, 1993 - 14,4\%), (Marcinčin-Beblavý, 2000, p. 27) and new social problems let to vigorous criticism of the reform process by many Slovak economists who believed it was harmful to the country.

The political elite focused on the elections which took place in June 1992; the question of the state law represented an important topic in the election campaign, therefore there was no ambition to solve the problem before the elections. The results of the elections of June 1992, predestined the direction of the further development of the state law system. In the Slovak National Council, Hnutie za demokratické Slovensko (HZDS, Movement for Democratic Slovakia) won (37.26\%), Strana demokratickej lavice (Democratic Left Party) ranked second (14.70\%) followed by KDH (Christian Democratic Movement; 8.89\%), SNS (Slovak National Party, 7.93\%) and the Hungarian Coalition (7.42\%)(Statistical Office of The Slovak Republic, 2018). In the Czech Republic Občianska demokratická strana- ODS (Civic Democratic Party) won.

The result was a very strange situation in relation to the ideological and political proportion of powers, and their manifestation in party representation at the national parliament. In the Czech Republic the right wing won the 
elections, but on the other hand in Slovakia the triumphant parties were from the Centre and Left Wing, and moreover, nationally oriented. In this situation, to create a functional federal government was technically possible, but only by maintaining a pragmatic approach and interest to preserve a common state (Krejčí, 2006).

The leaders of both winning parties, Vladimír Mečiar (HZDS) and Václav Klaus (ODS), became the prime ministers of the respective republic governments. It was expected that these leaders together with the federal government and the federal parliament would create conditions and a legitimate framework for the shared country to separate.

On $3^{\text {rd }}$ July 1992, the presidential candidate Václav Havel failed to receive the required majority of votes. On 17th July, the Slovak National Council announced the Declaration of Independence of the Slovak Nation (out of 150 SNC members, 113 voted in favour, 24 against, and 10 abstained). After its adoption the president of Czech and Slovak Federal Republic, Václav Havel, resigned from office. The Constitution of the Slovak Republic was approved on 1st September 1992, and entered into force on 1/10/1992 (Kováč, 1998, p. 322).

The leading political elite was not interested in seeking a compromise that would maintain the shared state, even though the public opinion surveys at that time showed that most citizens did not want Czecho-Slovakia to separate. It led to the decision to vote on the topic of the constitutional law, according to which the Czech and Slovak Federative Republic would divide; the results were submitted to the Federal Assembly which accepted them on $25^{\text {th }}$ November 1992. Subsequently, the referendum on the state law system did not take place, since it could possibly jeopardise the leading positions acquired by the political powers in the June elections.

Czecho-Slovakia separated into the Czech Republic and the Slovak Republic as of $1^{\text {st }}$ January 1993. The separation of Czecho-Slovakia was highly cultured, and Europe accepted it with a deep understanding. Despite the new situation, close cooperation between Czechs and Slovaks, as nations with an extraordinarily close relationship, continues to this day and develops in all areas of politics, economy, education and culture (Terem, 2015, p. 24). 


\section{THE INTERNAL POLITICAL DEVELOPMENT IN THE 90'S AND ITS IMPLICATIONS ON THE INTERNATIONAL POSITION OF THE INDEPENDENT SLOVAKIA}

The civilized dissolution of the federal state of Czechoslovakia, as well as the fact that the new Slovak Republic subscribed to the succession of Czechoslovakia, and not to the wartime Slovak state, accelerated the process of international recognition of the new state. Since the first day of its existence, Slovakia became a Member State of the CSCE (OSCE) and the NACC (North Atlantic Cooperation Council); then on 19th January 1993 a member of the UN; in June 1993 a member of the Council of Europe; and on 4th October 1993 Slovakia signed the Europe Association Agreement between the European Community and its member states, which entered into force on 1st February 1995. Slovakia has hereby become a definite subject of intentional law (Vlček, Kaščáková, 2010, p. 19).

In Slovakia it was first necessary to formulate fundamental assumptions and approaches to international political issues and set priorities of foreign policy in a new international political situation. Before 1989, Slovakia was defined by its affiliation towards its allies of the USSR, which was duly reflected also in the formulation of its foreign policy and security orientation. The collapse of the socialist system ended an era defined by foreign policy controlled by Soviet interests. Czechoslovakia and later the independent Slovak Republic had to define their own foreign policy concepts, which would respect the new status, interests and opportunities on the international political scene. Slovakia had yet to face the specific problems which resulted from its historical experience and geopolitical position in which it was located.

An unclear orientation of Slovakia in the era of forming a new political and intellectual elite resulted during the first half of the 90's in various alternatives to foreign policy orientation. One of them was the idea to present Slovakia as a "bridge between the West and the East". Another approach was to follow the example of a neutral Switzerland, and a rather strong wing promoted Slovakia's incorporation into the Euro-Atlantic structures. These ideas were the result of a lack of a society-wide consensus on the future character of the county's direction, definition of national interest and its manifestation in the foreign policy orientation. This situation was the result of, inter alia, an absence 
of qualified political elites with Western education. The development of foreign policy was thus very closely linked to internal political developments, as the matter of choice between integration into the Western world or finding another solution to the central foreign policy debate.

The internal political and economic development in the first decade of the existence of the independent Slovak Republic was marked by the struggle for the democratic nature of the country with a prosperous market economy and a pro-Western orientation.

By 1993, moreover, the bitter fights over national identity, secession, economic transformation, and the prime minister V. Mečiar's intolerant and somewhat undemocratic leadership style, had greatly divided Slovakia's political elites. A self-styled „civic-democratic"opposition formed to counter the nationalist populism of Mečiar's HZDS. Comprised originally of ex-federalists, the opposition eventually included former secessionists and a sprinkling of opportunists who had lost power struggles with V. Mečiar (Szomolányi, 1999, p. 28).

The idea of a typical competition between right, center and left-wing parties was achieved only partially. The rivalry did not take place on the level of values and ideas; it turned into a power struggle of the leaders, political styles, ethnic and national issues, nation and state concepts (ethnic versus civic) and attitudes towards the Czech and Slovak Federal Republic separation. Three main political blocs emerged: centre-right parties, left-wing parties and national-populist parties. Their mutual interactions determined the establishment of governmental coalitions. The proportion between the individual parties within the blocs further determined the policies adopted by the governmental coalitions (Mesežnikov, 2010, p. 50).

After the 1992 election, HZDS formed the government with a silent, and later an open support of SNS (Slovak National Party). In the New Year's speech of 1994, the President M. Kováč proposed the establishment of a broad coalition in order to overcome the instability of the political parties. The HZDS members criticized the President widely for such remarks. On the other hand, the President, in his Parliament speech from March 1994, criticized them for concentrating too much power into their own hands. Groups of moderate politicians had already split off from both sides, part of them created the liberal Democratic Union (DÚ). In March 1994 the governmental 
coalition lost its majority in the Parliament and V. Mečiar's government was substituted by that of Jozef Moravčík; the latter consisted of members of DÚ (Democratic Union), KDH (Christian Democratic Movement) and the Party of the Democratic Left (SDL). Thanks to the Hungarian parties the coalition gained sufficient support. The condition upon which SDL entered the coalition was that parliament elections were to take place in October 1994 (SDL preferences were increasing at the time).

The 1994 elections were dominated by HZDS/Movement for Democratic Slovakia which received $34.96 \%$ of votes (Statistical Office of The Slovak Republic, 2018).

The results of the 1994 parliamentary elections resulted in another coalition government led by V. Mečiar; it consisted of HZDS/Movement for Democratic Slovakia, SNS/Slovak National Party and the left-wing and populist ZRS (Union of the Workers of Slovakia). The opposition was represented by KDH, DÚ, SDL and the Hungarian party coalition, which all claimed loyalty to democratic values, rule of law as well as aversion towards authoritarianism. The division of the party system into democratic and authoritarian parties significantly affected the development in 1994-1998.

The 1994 elections resulted in political regression and in Slovakia's departure from the promising Central European way of transition that was followed by the Hungary, Czech Republic and Poland. This deviation was identified in the structural characteristics of the system of political parties, elite configuration and political culture (Szomolányi, 1994, p.31).

The national-populist parties in the coalition shared the authoritarian approach to power which conflicted with liberal democratic values. This approach was reflected in the limitation of free democratic competition, hampering social and economic reforms, efforts to control the economy, and privatisation.

Such development worried the democratically thinking part of the society, as well as the EU countries and the US. The governmental coalition did not respond positively to the diplomatic measures taken by the EU and US. The EU therefore opted for a sharp detour, pointing out the conflict between the governmental coalition's practices and the democratic standards in the EU 
countries. The failure to meet the democratic standards became the reason why Slovakia was not invited to enter NATO and the EU along with its neighbours (CZ, Hungary, Poland). Paradoxically, the governmental coalition declared an interest to enter NATO and the EU, despite creating conditions under which such integration was impossible. In fact, the foreign policy orientation of Slovakia towards the EU and NATO was of vital importance for the state.

The formation of the liberal democratic regime after the gaining of independence was significantly affected by external actors, mainly NATO and the EU. At its session in Copenhagen in 1993, the European Commission (EC) established basic membership requirements for candidate countries. The most important membership requirements included the stability of institutions that guarantee democracy, rule of law, protection of human rights and minorities, i. e. a liberal democratic political regime. The next category of requirements addressed the existence of a market economy and the ability to adopt and implement the legal framework of the European communities (acquis communitaire). Meeting these requirements represented an elementary precondition for a country to be invited to join the EU accession negotiations.

Slovakia at that time did not fulfil them in a satisfactory manner, the political criteria set by the European Council in Copenhagen, given the instability of its constitutional institutions and weak democracy governance. Based on this assessment, the European Council in Luxembourg in December 1997 did not recommend to open accession negotiations with Slovakia. Slovakia was thus omitted from the integration process. A similar situation evolved in the case of the NATO membership, when Slovakia, unlike its neighbours: the Czech Republic, Poland and Hungary, did not receive an invitation to join NATO. Moreover, the accession of Slovakia to the OECD was postponed as well.

It was evident that in 1994-1998 the governmental coalition jeopardized the democratic foundation of the state, its law and escalated the polarisation of the society, propelling Slovakia into international isolation. It was a purposeful attempt to introduce the authoritarian rule (Holec, 2013, p.11).

The population's gradually increased support for democratic principles was observed as early as 1997, this political and socio-cultural shift was confirmed by the voting behavior of the majority of citizens in the 1998 elections. 


\section{THE VICTORY OF PRO - INTEGRATION POLICY}

At last, Slovakia found the inner strength to work on its existential issues. Thanks to the relentless efforts, after 1998 Slovakia began to meet the criteria for the EU membership. Policy changes after the elections in 1998 were positively evaluated during the summit of the Heads of State and Government in Vienna. The summit concluded that the 1998 elections presented Slovakia with the chance to resolve its political problems and take steps towards the fulfilment of political criteria necessary to join the EU. In May 1999, for the very first time a direct presidential election was held in Slovakia, which ended a 15 month period of negligent presidency, and initiated the stabilization of the political system. The law on the use of minority languages in official communications was adopted in July 1999. Slovakia aligned its legislation in this field accordingly to the demands of the OSCE, Council of Europe and the European Commission.

Based on this progress the European Council in Helsinki, in December 1999, concluded that Slovakia meets the Copenhagen political criteria and extended an invitation for talks on accession. Slovakia's accession process has confirmed a principle of a catch-up process, and in the number of closed chapters caught up the other Visegrad countries. In 2004, the Slovak Republic became a member of the EU and also a NATO Member State.

The pro-western foreign policy wing of Slovakia is neither specific, nor stripped of its broader historical context. The western orientation belongs to the basic characteristics of the political and public life of Central European countries, as all of them share a received key civilisation impulse from the West. The relationship towards the West also relates to the quality of democracy, country's relationships and public life standards. By breaking the bonds with the West and inclining towards the East (Russian annexation of Poland, Ottoman annexation of the Hungarian Kingdom, Soviet annexation of Central Europe), the emancipation of these nations and countries had been previously considerably delayed (Drulák, 2012, p. 34).

EU positively influenced the political debate in Slovakia and has helped to create a domestic political consensus on further foreign policy direction of the country, as well as contributed to the creation of instruments of political control. It was shown that the formation of the liberal democracy, after the 
gained independence, was an important or even crucial factor influenced by external factors, particularly joining NATO and the EU. The influence of the European Union was most prominent in the pre-accession phase, and since Slovakia became a member, the influence is mainly on the form of the foreign policy agenda. Hence, Slovakia incorporates problems and issues that are beyond its traditional foreign policy interests and priorities. NATO has had the same impact, however it was more visible during the pre-accession period, as the fundamental conditions for membership are inherently compatible with a liberal democracy regime. Slovakia through its participation in NACC and PFP (Partnership for Peace) and MAP (Membership Action Plan) implemented various elements of the democratization of society (Duleba, Bilčík, Klavec, Korba, 2006). The country has committed itself to respect fundamental principles of the NATO founding treaty - the Washington Treaty, to protect the freedom, common heritage and values of all Alliance members.

Foreign and security policy of the Slovak Republic in the global context is limited to its size, human resources and small economic potential. Slovak membership in global organizations such as the UN or the OECD does not guarantee the enforcement of its national interests to an adequate extent. Therefore, it can be concluded that the best way to face this, is to use the membership in NATO and in the EU. Slovak membership in these two organizations creates qualitatively new dimensions to its position, not only in Europe, but also in the global framework. At the same time, Slovakia gained a new high level of its international security, socio-economic stability, and a basic prerequisite for a higher rate of economic development, and thus living standards can increase for its citizens (Gubáš, 2003).

For the international position of Slovakia, it is important to reflect on the changing nature of allied American ties. The US impact on the global military, economic, cultural and political spheres is crucial (Terem, 2017, pp.119). In terms of unipolarity, the first decade of the $21^{\text {st }}$ century, USA inclined more towards the formation of alliances based on security and military cooperation with selected countries. Slovakia, along with other Central European countries, perceived the accession to NATO as a safeguard mechanism against the case of a possible neighbourly dispute, potential renewed threats from the Russian Federation, or against potential security 
threats arising from current global developments. A natural part of these processes was aligning the foreign policy interests with those of the USA. Slovakia in its history repeatedly confirmed the logic that "small powers set their course accordingly to the big powers "(Carr, 1939, p.134). This is called "bandwagoning", it expresses the desire of small states to align themselves with big powers and to trust in their good intentions. As for the US, as well as in case of previous conflicts (Cold War- USSR, Second World WarGermany), these alliances were determined by the geopolitical situation at that time, which was reflected in the compatibility of political regimes.

Given the clearly declared interest by the Slovak society, after 1989, the Slovak state started to form its democratic values with a Western prointegration foreign policy orientation, and thus the USA became a natural ally of Slovakia. Some authors argue that some countries may not only be close or distant in a geographical sense but also in other ways. The degree of similarity or differences between such countries - called "distance", is reflected in terms of political, economic, cultural and other areas - this may be the key role to the content and type of transactions between them. Generally speaking, the more similar the political, economic and cultural characteristics are, the higher the level of trade, communications and other forms of interaction. Foreign policy and security ties with the USA determined the priorities of the Slovak foreign, security and defence policy (e.g. Foreign policy strategy of Slovakia until 2015, the Security strategy of 2005, etc.). Slovakia together with the US operates in many problematic regions of the world, as in various military and in civilian operations. Allied ties are enforced also by the cooperation in the fight against terrorism. A positive development is also present in the field of economic cooperation, investment and transfer of technologies (Terem, Lenč, 2015, p. 677).

Slovakia has come forward with interesting initiatives during its EU Presidency, addressing the institutional balance, strengthening the position of national parliaments, improving the resilience of the $\mathrm{EU}$ as a whole, enhancing the internal market: energy union, single digital market, capital market union, inviolability of the free movement of persons, goods, service and capital. In the European Commission negotiations regarding free trade, the SR aims for results that respect the Slovak interests. The SR also continually points out the need to support the eastern dimension of the 
European neighbour policy and the enlargement the EU in that sense. It also addresses the southern pillar of the neighbour policy, due to security reasons (EU in the 2016-2020 Government Statement..., 2016).

The V4 cooperation remains an important priority, mainly in the areas of high significance for the whole region. These areas include energy and transport infrastructures, external energy security, defence and security as well as sharing experience with the transformation process and integration among the Eastern Partnership countries. The implementation of the EU strategy in the Danube region provides opportunities for the Central European region in broader terms. The strategic objective in relation to Ukraine is to support its transformation process and reforms, in order to help Ukraine approach the EU. The development of cooperation between the EU and the Eastern Partnership countries remains a priority for the SR foreign policy. Besides the traditionally declared support for reformative processes, these countries implemented specific initiatives promoting mobility (liberalisation of the visa regime) and educational cooperation. Opening of the embassy in Chișinău, and the ambition to provide direct diplomatic representation in the Transcaucasia region, confirm the objectives declared by the Slovak foreign policy in the Eastern Partnership countries.The similar approach can be observed in the Slovak foreign policy towards the Western Balkans (Montenegro, Serbia, Macedonia, Bosnia and Herzegovina, Albania). The political support and assistance in the Montenegrin effort to integrate into the European structures brings positive results. Traditionally, the Slovak diplomacy is active in Serbia, including in the promotion of a dialogue between Belgrade and Pristina (Rosputinský, 2017). Slovak NGOs are extraordinarily active in Ukraine, Belarus, Georgia, Serbia and Montenegro.

In relation to other $\mathrm{EU}$ member states, main attention is paid to improving of economic cooperation, the course of the integration process, and strengthening the EU position as a global player.

\section{CONCLUSION}

The message of the November events (the Velvet Revolution) of 1989 has opened up a space for the current and future position of Slovakia in the world. NATO Membership provides Slovakia with opportunities for participating 
in the shaping of international policy and security environment. Slovakia has assumed responsibility for the success of some NATO operations (Afghanistan, Iraq, Kosovo, Bosnia and Herzegovina). The ideals of the so called "Velvet revolution" in November 1989 still determines much of the Slovak political scene's emphasis on respecting democratic principles, freedom and democracy expansion, respect for human rights, rule of law and a consistent rejection of nationalism, radicalism, extremism and racism.

Many indicators point to the increased dynamics of changes in the global, international and security environment. Many analyses accentuate the power decline of Europe, which in the context of other problems in the political, security, economic and social sphere leads to a growing number of questions about the future stability and cohesion of the EU itself. We should not marginalize internal problems of NATO either, problems which do not only touch upon question of resources, but mainly its identity. It is necessary to actively support the transatlantic partnership, which in the three key periods (World War I, World War II, the Cold War) produced positive results for the future of a united Europe, of which Slovakia is also a part of.

Seeking and finding of a consensus policy is a prerequisite for the Slovak foreign, defence and security policy, to be able to utilize the space offered to promote the State's interests and active participation in forming of a safer world for small countries, in which they can rely on the norms of international law and adherence to them; to ensure stability, territorial sovereignty and prosperity, and the power to suppress the logic of geopolitics that perceives the territory of small states as a forms of a "buffer zone" or "weights balance" in the strategies of political powers. The EU membership meant for Slovakia an opportunity to participate in a club in which it was possible, in the relations between States, to eliminate the threat and the use of violence. It is a community in which real common guarantees assure of no use of force when disputing and dealing with problems. Given the EU importance for the stability and prosperity of Slovakia, it will be important to assume such positions that won't be susceptible to weaken the achieved level of integration and at the same time would be in favour of expanding the area of stability in the periphery of Europe. 


\section{References}

Baar, V. (2000). Geopolitický vývoj Evropy In: IVANIČKA, K. (ed.) (2000). Dynamické vývojové procesy a štruktúry a ich medzinárodný kontext. Banská Bystrica: Fakulta politických vied a medzinárodných vztahov. ISBN 800553718, p. 126-136.

Carr, E, H.(1939). The Twenty Years' Crisis 1919-1939. An Introduction to the Study of International Relations. London: Macmillan, pp.134.

Drulák, P. (2012).Slovensko, Česko a Západ. Zahraničná politika. [online]04/2012. SFPA. [cit. 10.09.2018] Available on the Internet< http://zahranicnapolitika.dennikn.sk/slovensko-cesko-a-zapad/>, ISSN1339-8121,pp.34.

Duleba, A. Bilč́́k, V. Klavec, J. Korba, M. (2005). „Vonkajšie bezpečnostné hrozby a riziká". In: SZOMOLÁNYI, S.(ed.)2005. Spoločnost' a politika na Slovensku. Cesty k stabilite 1989-2004. Bratislava: UK, 2005. ISBN 8022320773, p. 324-337.

EurActiv: EU in the 2016-2020 Government Statement. Online [cit. 2016-09-10]. Available on the Internet: <http://euractiv.sk/fokus/buducnost-eu/eu-v-programovom-vyhlaseni-vlady-2016-2020/> .

Gubáš, F. (2003).Ekonomické aspekty obrany a bezpečnosti Slovenskej republiky. Inštitút obrany a bezpečnosti,Ministerstvo obrany Slovenskej republiky, Bratislava 2003, pp.45.

Holec, R. (2013). Dvadsat rokov pohladom historika. In: Bútora, M.-Mesežnikov, G.-Bútorová- Kollár, M. (2013). ODKIAl'A KAM. Dvadsat rokov samostatnosti. Bratislava: Inštitút pre verejné otázky, Kalligram. ISBN 9788089345427, pp. 11.

Kováč, D.(1998). Dejiny Slovenska. Nakladatelství Lidové noviny. ISBN 8071062685 , pp.316-323,331-334, 337-338.

Krejčí, O.(2006). Nová kniha o volbách, Professional Publishing 2006, str. 299-300, p. 484 ISBN 8086946010.

Marcinčin, A. 2000. Úvod. In: Marcinčin, A. Beblavý, M.(ed.): Hospodárska politika na Slovensku 1990-1999, SFPA, Centrum pre spoločenskú a mediálnu analýzu, INEKO, Bratislava 2000, p.15, ISBN 8096814710.

Mesežnikov, G. (2010). Politické strany a stranícka politika po Novembri '89. In: Bútora, M. Kollár, M.-Mesežnikov, G. Bútorová, Z. (eds.) 2010. KDE SME? Mentálne mapy Slovenska. Bratislava: Inštitút pre verejné otázky, Kalligram. ISBN 9788089345199, pp. 44-45,47- 48, 50, 56,57, 59.

Morvay, K. (2000).Celkový makroekonomický vývoj. In: Marcinčin, A.-Beblavý, M.(ed.): Hospodárska politika na Slovensku 1990-1999 Bratislava: SFPA, Centrum pre spoločenskú a mediálnu analýzu, INEKO, ISBN 8096814710, pp. 27,34-35 . 
Rosputinský, P. (2017).Praktikum z diplomatického práva a konzulárneho práva - 2 . rozš. a aktualiz. vyd. - Bratislava: PAMIKO, 2017. - 190 s. [10,05 AH]. - ISBN 9788085660135 .

Sičák, A.(2006). Česko-slovenské vztahy v minulosti, filozofické aspekty spôsobu života v našom časopriestore na prelome dvoch tisícročí. In: Ištok,R.(ed.): Transformácia politicko-priestorových systémov a systémov demokracie, Fakulta humanitných a prírodných vied, Prešovská univerzita, Prešov, ISBN 8080685002. pp.176-188.

Statistical Office of the Slovak Republic Online [cit. 2018-10-02]. Available on the Internet<https://slovak.statistics.sk/wps/portal/ext/themes/elections/parliament/ about/>.

Szomolányi, S.(1994). Does Slovakia Deviate from the Central European Variant of Transition? In: Szomolányi, S., Mesežnikov,G. (eds.) Slovakia: Parliamentary Elections 1994. Causes-Consequences-Prospects. Bratislava: Slovak Political Science Association and Friedrich Ebert Foundation.

Szomolányi, S.(1999). Slovakia between Eastern and Central European Ways of Transition. In: Dvořáková, V. (ed) Succes or Failure? Ten years after. Česká společnost pro politické vědy, Slovenské združenie pre politické vedy. Praha, ISBN: 8090217621, pp. 28, 34 .

Terem, P. (2015).Slovakia in Central Europe - geopolitical aspects. chapter 1. In: Terem, P.-Čajka, P. Rýsová, L. 2015 Slovakia in geopolitical and geo-economic context.1. vyd. - Praha: Professional Publishing, 2015. - ISBN 9788074311208. pp. 6-38 .

Terem, P.- Lenč, M. (2015).Význam spojeneckých väzieb a súčasné smerovanie európskej zahraničnej politiky Slovenskej republiky. In: Bittmanová, B. - Vlková, E. (eds.): International relations 2015. Current Issues of World Economy and Politics. Publishing Ekonóm 2015. ISBN 9788022542197, pp.674-686.

Terem,P.(2017). Globálne mocnosti - vybrané aspekty amerického líderstva. Politické vedy 1/2017 ročník XX. Banská Bystrica: Belianum, Matej Bel University Press ISSN 1335-2741. pp. 105-131.

Vlček,D.-Kaščáková,D.(2010). Zahraničná politika Slovenskej republiky. Banská Bystrica: FPVMV UMB 2010. ISBN 9788055700427, pp. 15-22. 